Jpn. J. Genet. (1985) 60, pp. 411-424

\title{
Studies on the origin of crop species by restriction endonuclease analysis of organellar DNA. I. Phylogenetic relationships among ten cereals revealed by the restriction fragment patterns of chloroplast DNA1)
}

\author{
By Shin-ichiro Enomoto ${ }^{2)}$, Yasunari OGIhara ${ }^{2)}$ and Koichiro Tsunewaki \\ Laboratory of Genetics, Faculty of Agriculture, Kyoto University, \\ Sakyo-ku, Kyoto 606
}

(Received July 1, 1985)

\begin{abstract}
The phylogenetic relationship of ten crops selected from all the seven tribes of the Gramineae which contain crop species, i.e., wheat, rye and barley from Triticeae, oats from Agrosteae, finger millet from Chlorideae, foxtail millet from Paniceae, sorghum from Andropogoneae, maize and job's tears from Maydeae, and rice from Oryzeae, were studied by restriction endonuclease analysis of their chloroplast (ct) DNAs. Three enzymes, KpnI, PstI and SalI which are known to give rise to fewer restriction fragments from the cereal ctDNAs than other enzymes were used. For each restriction fragment pattern, the copy number and molecular size of the individual fragments were estimated. From these data, genetic distance $(\hat{p})$ between chloroplast genomes of the ten cereals were calculated using Engels' formula (Engels 1981), based on which their phylogenetic tree was constructed by the UPGMA method of Sneath and Sokal (1973). This phylogenetic tree is in complete agreement with that made from ordinary systematic studies (Tateoka 1957), except for one point, i.e., the genetic distance between the chloroplast genomes of sorghum and maize or job's tears which belong to different tribes is closer than that between maize and job's tears which belong to the same tribe. Thus, the two genera, Zea and Coix appear to be better placed in separate tribes. The critical $\hat{p}$ value to separate two taxa into different tribes, subfamilies_and families was about $\hat{p}=0.02,0.05$ and 0.12 , respectively.
\end{abstract}

\section{INTRODUCTION}

The agarose gel electrophoresis of restriction endonuclease digests of organellar DNAs has become a new technique in plant genetics (Atchison et al. 1976; Bedbrook and Bogorad 1976; Levings and Pring 1976; Vedel et al. 1976). In various plant genera, both chloroplast (ct) and mitochondrial (mt) DNAs

1) Contribution from the Laboratory of Genetics, Faculty of Agriculture, Kyoto University, Japan, No. 477. The work was supported in part by a Grant-in-Aid (No. 60400005) from the Ministry of Education, Science and Culture, Japan.

2) Present addresses: College of Biological Sciences, University of Minnesota, St. Paul, Minnesota 55108, USA, and the Max-Planck-Institute for Molecular Genetics, Ihnestrasse 63-73, D1000, Berlin 33 (Dahlem), FDR, respectively. 
show great diversity in their restriction fragment patterns, and the analysis of these patterns has proved to be a powerful tool to clarify the phylogenetic relationships among the species in several taxa, such as Triticum and Aegilops (Vedel et al. 1978; Ogihara and Tsunewaki 1982; Terachi et al. 1984), Zea (Timothy et al. 1979), Oenothera subsection Euoenothera (Gorden et al. 1982), Nicotiana (Kung et al. 1982), Lycopersicon (Palmer and Zamir 1982), Coffea (Berthou et al. 1983), Brassica (Palmer et al. 1983), legumes (Palmer et al. 1983), Pennisetum (Clegg et al. 1984) and tuberous Solanum (Hosaka et al. 1984).

Encouraged with these works, we have been studying phylogeny of important crop species by comparative analysis of restriction fragment patterns of organellar DNAs between the crop species and their wild relatives, to shed new light on the origin of the crop species. The family, Gramineae, is divided into five subfamilies and 43 tribes, only seven of which contain cereal crops. The present article, the first report of this series, aims to clarify the phylogenetic relationships among ten crop species belonging to these tribes by the analysis of restriction fragment patterns of their ctDNAs. The results of this study will be compared with those previously obtained by the traditional systematic studies. As reported below, the results have demonstrated that this approach provides useful informations on both the intra- and intertribal phylogenetic relationships.

\section{MATERIALS AND METHODS}

Ten cereal crops, all belonging to the family, Gramineae, were used in the present investigation. Their lower taxonomic statuses are shown in Table 1. In the foregoing sections, they are called by their common names. Seeds of wheat and job's tears were obtained from the Kyushu Agricultural Experiment Station, Chikugo, and the Chugoku Agricultural Experiment Station, Fukuyama, respectively. Rice seeds were a gift from the Agricultural Research Center, Ministry of Agriculture, Forestry and Fishery, Tsukuba. All other materials were derived from the stock collection of our laboratory.

Seeds of all cereals, except rice, were sown in wooden flats which were kept in a greenhouse or outdoors depending upon the season and species to obtain optimal growth. Rice seeds were sown in flats immersed in water, which were kept outdoors during summer. When seedlings reached a height of about $10 \mathrm{~cm}$, sometimes more to compensate the shortage of seeds, their leaves were collected and used for chloroplast isolation. The regenerated leaves were also used for the same purpose. The plants were kept in darkness for $24 \mathrm{~h}$ prior to leaf collection.

The isolation of intact chloroplasts, the preparation of ctDNA from the isolated chloroplasts, and the analysis of restriction fragment patterns of 


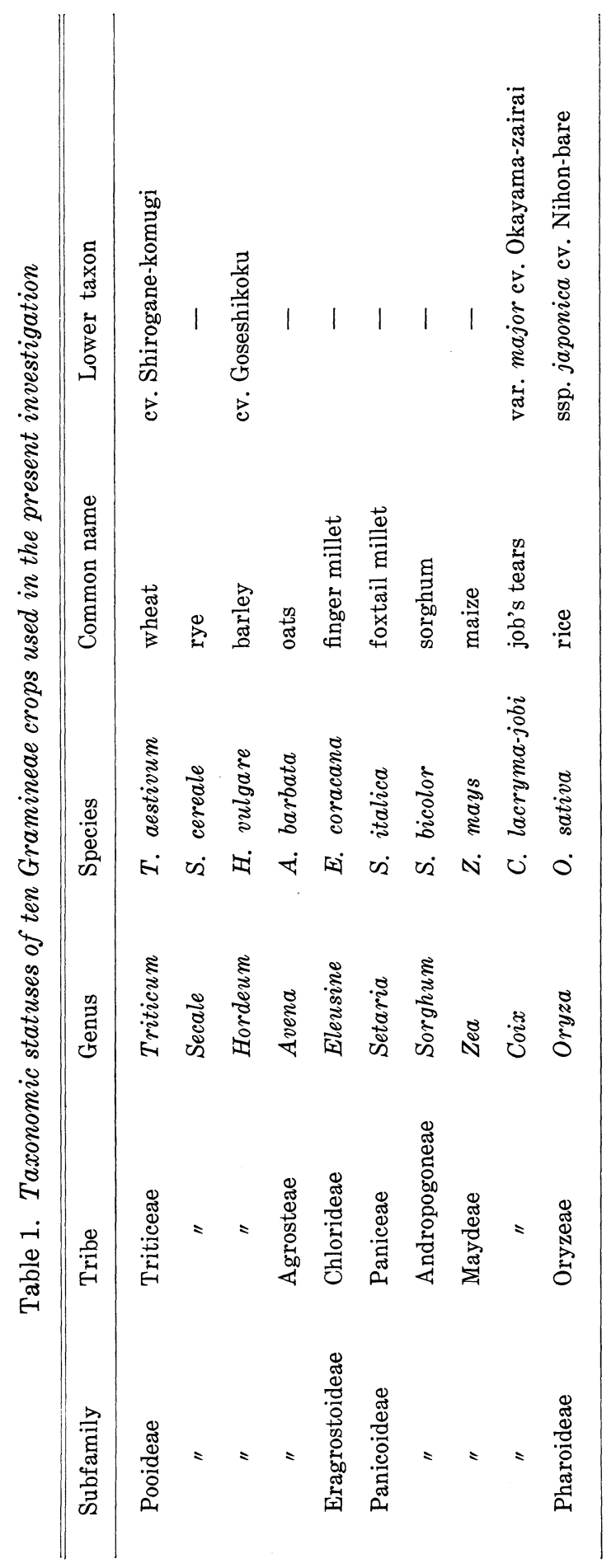


ctDNAs from all materials, except rice, were carried out according to the procedures of Ogihara and Tsunewaki (1982) and Tsunewaki and Ogihara (1983). Because rice ctDNA prepared by their method was not digested by any restriction endonuclease, we used the liquid nitrogen method for crushing leaves of this crop.

Three restriction endonucleases, KpnI, PstI and SalI, each of which recognizes and restricts a unique six base-pair sequence, were used. The reason for this choice is as follows; as the ten species studied belong to different subfamilies, large variation was expected among their ctDNAs so that we preferred to use the enzymes which give rise to only a small number of ctDNA fragments. The three endonucleases chosen here gave the fewest fragments in wheat and its relatives among the ten enzymes previously employed (Ogihara and Tsunewaki 1982, 1984).

The molecular size of each restriction fragment was estimated by performing three runs with $0.4,0.8$ and $1.2 \%$ agarose gel. Size markers used were undigested, EcoRI-, HindIII-, KpnI- or XhoI-digested, and EcoRI-HindIII double digested lambda phage DNA. Sometimes the BamHI-digested wheat ctDNA was used, because molecular sizes of almost all fragments were reported by Bowman et al. $(1981,1983)$.

The genetic distance, $\hat{p}$, between each pair of chloroplast genomes was estimated according to the method of Engels (1981) from the formula, $\hat{p}=$ $[c-2(m-k)] / j c$, where $c$ and $m$ are the total numbers of restriction fragments and restriction sites, respectively, in two ctDNA molecules, $k$ is the number of differential restriction sites between the two molecules, and $j$ is the length of a recognition sequence (six for all the three endonucleases). Procedures to obtain $m$ and $k$ from the present data are given in Engels (1981) and Terachi et al. (1984).

\section{RESULTS AND DISCUSSION}

Figs. 1, 2 and 3 show the restriction fragment patterns of ctDNAs of all species except for rice, obtained by the KpnI, PstI and SalI digests, respectively. The three patterns of rice ctDNA obtained by these digests are compared with those of wheat ctDNA in Fig. 4. Estimated molecular weights of all restriction fragments and their copy numbers are given in Table 2 to 4 .

The total chloroplast genome size appears to differ among the cereal crops belonging to different subfamilies. Wheat, rye, barley and oats of Pooideae and finger millet of Eragrostoideae had a genome size of about $135 \mathrm{kbp}$, whereas foxtail millet, maize, job's tears and sorghum of Panicoideae had a ctDNA molecule of about $140 \mathrm{kbp}$. The chloroplast genome size of rice belonging to Pharoideae was estimated to be about $135 \mathrm{kbp}$. Bedbrook et al. (1979), Bowman et al. (1981) and Hirai et al. (1985) estimated the chloroplast 


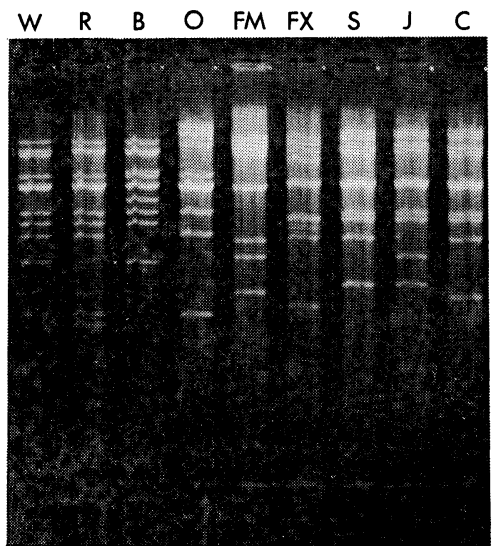

Fig. 1.

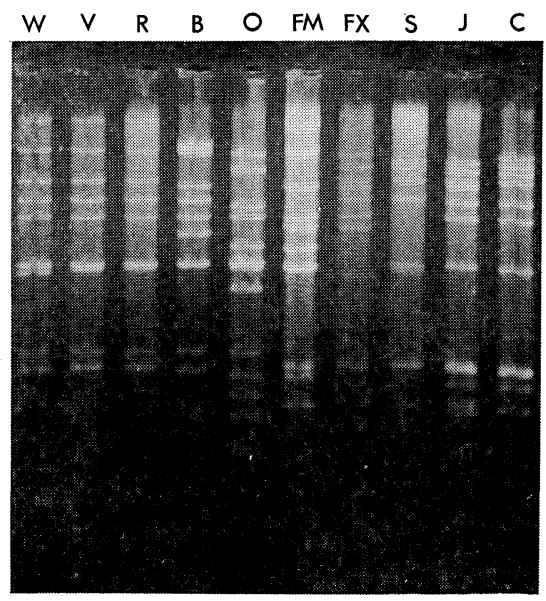

Fig. 2.

Fig. 1. KpnI-restriction fragment patterns of ctDNAs of nine cereals: $K p n I$-digested ctDNA was electrophoresed on $0.8 \%$ agarose gel. W: wheat, R: rye, B: barley, O: oats, FM: finger millet, FX: foxtail millet, S: sorghum, J: job's tears, and C: maize. Small fragments $(<2.0 \mathrm{kbp})$ could not be visualized on this gel (ref. Table 2).

Fig. 2. PstI-restriction fragment patterns of ctDNAs of nine cereals. (For explanation, see Fig. 1)

genome size of maize, wheat and rice to be $137,135.2$ and $130 \mathrm{kbp}$, respectively. Vedel et al. (1980) reported that the chloroplast genome size of wheat and oats is 81.8 and $81.9 \times 10^{6}$ daltons, respectively, i.e., that the genome size of wheat is similar to that of oats. The chloroplast genome size of wheat and oats we obtained were similar to that estimated by Bowman et al. (1981) and Vedel et al. (1980), respectively, but that of the maize and rice chloroplast genomes differs from the estimates made in previous works. In the SalI physical map of maize ctDNA drawn by Bedbrook et al. (1979), three small SalI fragments (1.1, 0.9 and $0.7 \mathrm{kbp}$, respectively) are not shown. If they are counted, the maize chloroplast genome is about $140 \mathrm{kbp}$ which is very close to our estimate. The rice chloroplast genome size we estimated is $5 \mathrm{kbp}$ larger than that reported by Hirai et al. (1985), which is due to the slightly larger molecular size of each fragment in our estimation than theirs; the restriction fragment patterns we obtained were identical to those they reported. These discrepancies must be solved in future works. So far as our estimates are concerned, the chloroplast genome size of Panicoideae appears to be larger than those of Pooideae, Eragrostoideae and Pharoideae.

From the data presented in Table 2 to 4 , the genetic distances ( $\hat{p}$ values) between chloroplast genomes of ten cereal crops were estimated using Engels' formula. The results are given in Table 5 . Based on these $\hat{p}$ values, a phylogenetic tree was constructed, as shown in Fig. 5, using the UPGMA (un- 


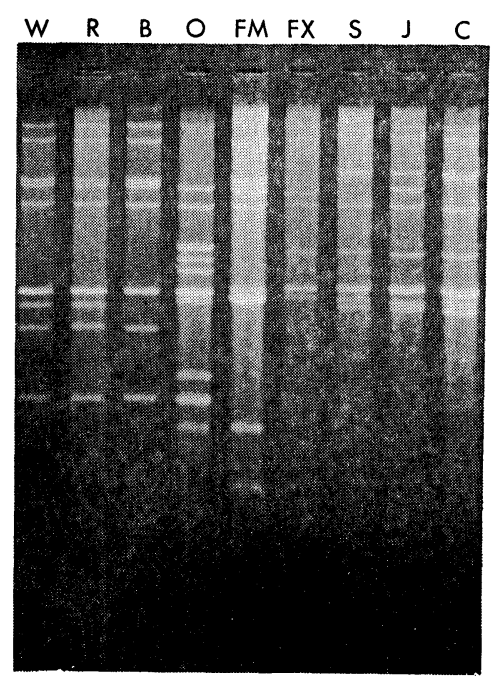

Fig. 3.

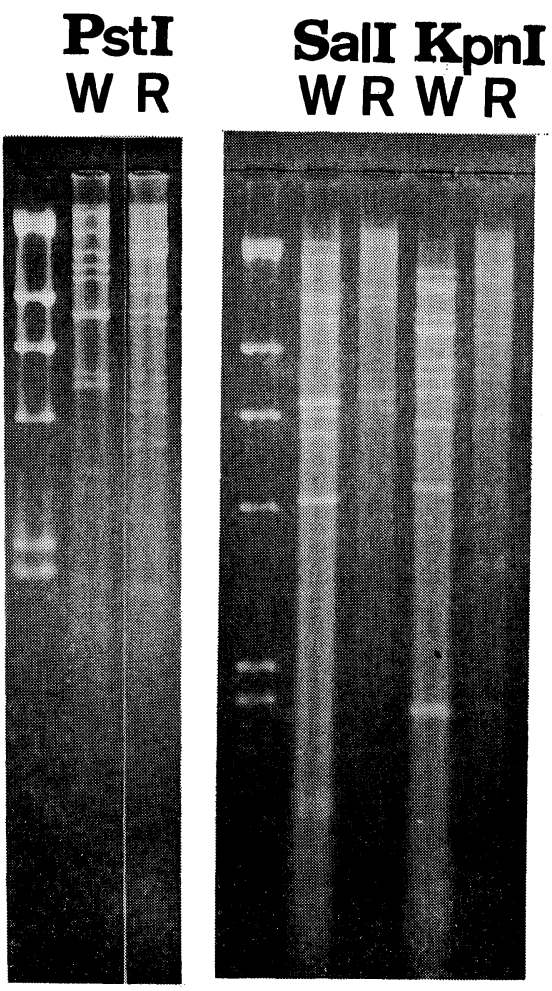

Fig. 4.

Fig. 3. SalI-restriction fragment patterns of ctDNAs of nine cereals. (For explanation, see Fig. 1)

Fig. 4. Restriction fragment patterns of ctDNAs of rice (R) and common wheat (W). $K p n I, P s t I$ and SalI refer to the KpnI, PstI and SalI digests, respectively. (HindIIIdigested lambda DNA is shown as the molecular size marker.)

weighted pair-group mean arithmetic average) method of Sneath and Sokal (1973). This phylogenetic tree for the ten Gramineae crops is in complete agreement with that figured from the conventional systematic studies (Fig. 6), except for one point which will be discussed below.

Wheat, rye and barley, all of which belong to the same tribe, Triticeae, showed a high degree of fragment homology with each other. For example, of 45 fragments identified in the three patterns of wheat ctDNA, $39(87 \%)$ and $32(71 \%)$ had identical counterparts in rye and barley ctDNAs, respectively. Similarly, of the total of 41 fragments in the three patterns of barley ctDNA, $32(78 \%)$ and $30(73 \%)$ had homologous counterparts in wheat and rye ctDNAs, respectively. The genetic distances between the three chloroplast genomes were $0.011-0.021$ (Table 5), indicating that they are very closely related. The wheat-rye relationship was closer than the wheat-barley and 
Table 2. Molecular size (kbp) and copy number of individual KpnIrestriction fragments of ctDNAs of ten cereals

\begin{tabular}{|c|c|c|c|c|c|c|c|c|c|}
\hline \multicolumn{2}{|c|}{ Wheat } & \multicolumn{2}{|c|}{ Rye } & \multicolumn{2}{|c|}{ Barley } & \multicolumn{2}{|c|}{ Oats } & \multicolumn{2}{|c|}{ Finger millet } \\
\hline $\begin{array}{l}\text { Copy } \\
\text { no. }\end{array}$ & $\begin{array}{l}\text { Mol. } \\
\text { size }\end{array}$ & $\begin{array}{c}\text { Copy } \\
\text { no. }\end{array}$ & $\begin{array}{l}\text { Mol. } \\
\text { size }\end{array}$ & $\begin{array}{c}\text { Copy } \\
\text { no. }\end{array}$ & $\begin{array}{l}\text { Mol. } \\
\text { size }\end{array}$ & $\begin{array}{c}\text { Copy } \\
\text { no. }\end{array}$ & $\begin{array}{l}\text { Mol. } \\
\text { size }\end{array}$ & $\begin{array}{c}\text { Copy } \\
\text { no. }\end{array}$ & $\begin{array}{l}\text { Mol. } \\
\text { size }\end{array}$ \\
\hline 1 & 18.0 & 1 & 18.0 & 1 & 18.0 & 1 & 24.6 & 1 & 19.6 \\
\hline 1 & 15.8 & 2 & 15.8 & 2 & 15.8 & 1 & 21.7 & 1 & 18.6 \\
\hline 1 & 15.4 & 1 & 11.8 & 1 & 12.4 & 1 & 18.0 & 1 & 17.2 \\
\hline 1 & 11.8 & 3 & 10.8 & 1 & 11.8 & 1 & 11.8 & 1 & 16.2 \\
\hline 3 & 10.8 & 1 & 8.85 & 2 & 10.8 & 2 & 10.8 & 1 & 15.3 \\
\hline 1 & 8.85 & 1 & 8.3 & 1 & 9.8 & 1 & 10.6 & 2 & 10.6 \\
\hline 1 & 8.3 & 1 & 7.4 & 1 & 8.85 & 1 & 8.85 & 1 & 7.2 \\
\hline 1 & 7.4 & 1 & 4.9 & 1 & 8.3 & 1 & 7.4 & 1 & 6.35 \\
\hline 1 & 6.3 & 1 & 4.55 & 1 & 6.3 & 1 & 4.9 & 1 & 5.3 \\
\hline 1 & 4.6 & 3 & 1.8 & 2 & 1.8 & 2 & 1.8 & 1 & 2.05 \\
\hline 3 & 1.8 & 2 & 0.8 & 2 & 0.8 & 2 & 0.8 & 2 & 1.9 \\
\hline 2 & 0.8 & 1 & 0.7 & 1 & 0.7 & & & 2 & 0.8 \\
\hline 1 & 0.7 & & & & & & & 1 & 0.6 \\
\hline 18 & 136.55 & 18 & 135.5 & 16 & 134.55 & 14 & 134.65 & 16 & 135.0 \\
\hline \multicolumn{2}{|c|}{ Foxtail millet } & \multicolumn{2}{|c|}{ Sorghum } & \multicolumn{2}{|c|}{ Maize } & \multicolumn{2}{|c|}{ Job's tears } & \multicolumn{2}{|c|}{ Rice } \\
\hline $\begin{array}{c}\text { Copy } \\
\text { no. }\end{array}$ & $\begin{array}{l}\text { Mol. } \\
\text { size }\end{array}$ & $\begin{array}{c}\text { Copy } \\
\text { no. }\end{array}$ & $\begin{array}{l}\text { Mol. } \\
\text { size }\end{array}$ & $\begin{array}{c}\text { Copy } \\
\text { no. }\end{array}$ & $\begin{array}{l}\text { Mol. } \\
\text { size }\end{array}$ & $\begin{array}{c}\text { Copy } \\
\text { no. }\end{array}$ & $\begin{array}{l}\text { Mol. } \\
\text { size }\end{array}$ & $\begin{array}{c}\text { Copy } \\
\text { no. }\end{array}$ & $\begin{array}{l}\text { Mol. } \\
\text { size }\end{array}$ \\
\hline 1 & 19.6 & 1 & 21.5 & 1 & 21.5 & 1 & 21.5 & 1 & 19.8 \\
\hline 1 & 17.2 & 1 & 20.0 & 1 & 20.0 & 1 & 20.0 & 1 & 18.5 \\
\hline 1 & 15.8 & 1 & 16.6 & 1 & 16.6 & 1 & 17.0 & 1 & 17.6 \\
\hline 1 & 14.3 & 1 & 15.8 & 1 & 15.8 & 1 & 15.8 & 1 & 14.2 \\
\hline 2 & 10.8 & 2 & 11.0 & 2 & 11.0 & 2 & 11.0 & 1 & 11.5 \\
\hline 1 & 10.6 & 1 & 10.7 & 1 & 10.7 & 1 & 10.7 & 1 & 11.0 \\
\hline 1 & 8.4 & 1 & 8.7 & 1 & 8.7 & 1 & 8.7 & 2 & 10.3 \\
\hline 1 & 7.8 & 1 & 8.4 & 1 & 8.4 & 1 & 8.4 & 1 & 8.5 \\
\hline 1 & 7.4 & 1 & 7.4 & 1 & 7.15 & 1 & 6.5 & 2 & 3.3 \\
\hline 1 & 5.0 & 1 & 5.6 & 1 & 5.2 & 1 & 5.6 & 2 & 2.0 \\
\hline 1 & 2.2 & 1 & 2.1 & 1 & 2.1 & 1 & 2.1 & 1 & 1.9 \\
\hline 1 & 2.05 & 2 & 0.8 & 2 & 0.8 & 2 & 0.8 & 1 & 1.8 \\
\hline 2 & 1.9 & 1 & 0.7 & 2 & 0.7 & 1 & 0.7 & & \\
\hline 2 & 0.8 & & & & & & & & \\
\hline 1 & 0.7 & & & & & & & & \\
\hline 18 & 138.05 & 15 & 141.1 & 16 & 141.15 & 15 & 140.6 & 15 & 136.0 \\
\hline
\end{tabular}


Table 3. Molecular size (kbp) and copy number of individual Pst Irestriction fragments of ctDNAs of ten cereals

\begin{tabular}{|c|c|c|c|c|c|c|c|c|c|}
\hline \multicolumn{2}{|c|}{ Wheat } & \multicolumn{2}{|c|}{ Rye } & \multicolumn{2}{|c|}{ Barley } & \multicolumn{2}{|c|}{ Oats } & \multicolumn{2}{|c|}{ Finger millet } \\
\hline $\begin{array}{c}\text { Copy } \\
\text { no. }\end{array}$ & $\begin{array}{l}\text { Mol. } \\
\text { size }\end{array}$ & $\begin{array}{c}\text { Copy } \\
\text { no. }\end{array}$ & $\begin{array}{l}\text { Mol. } \\
\text { size }\end{array}$ & $\begin{array}{c}\text { Copy } \\
\text { no. }\end{array}$ & $\begin{array}{l}\text { Mol. } \\
\text { size }\end{array}$ & $\begin{array}{c}\text { Copy } \\
\text { no. }\end{array}$ & $\begin{array}{l}\text { Mol. } \\
\text { size }\end{array}$ & $\begin{array}{c}\text { Copy } \\
\text { no. }\end{array}$ & $\begin{array}{l}\text { Mol. } \\
\text { size }\end{array}$ \\
\hline 1 & 33.3 & 1 & 33.3 & 2 & 20.0 & 1 & 18.6 & 1 & 33.0 \\
\hline 1 & 19.6 & 1 & 19.6 & 1 & 19.0 & 1 & 15.5 & 1 & 19.6 \\
\hline 1 & 14.5 & 1 & 14.5 & 1 & 13.5 & 1 & 11.8 & 1 & 13.5 \\
\hline 1 & 12.6 & 1 & 12.6 & 1 & 12.6 & 1 & 11.0 & 1 & 11.0 \\
\hline 1 & 11.0 & 1 & 11.0 & 1 & 11.0 & 1 & 9.2 & 1 & 10.5 \\
\hline 2 & 8.4 & 2 & 8.4 & 1 & 9.9 & 3 & 8.4 & 1 & 9.1 \\
\hline 1 & 8.1 & 1 & 8.3 & 2 & 8.4 & 1 & 7.5 & 2 & 8.3 \\
\hline 1 & 5.6 & 1 & 5.6 & 1 & 5.6 & 1 & 5.5 & 1 & 5.3 \\
\hline 1 & 5.3 & 1 & 5.3 & 1 & 5.3 & 1 & 5.1 & 1 & 5.05 \\
\hline 1 & 5.2 & 1 & 5.2 & & & 1 & 4.7 & 1 & 4.6 \\
\hline 1 & 1.9 & 1 & 1.9 & & & 1 & 4.3 & 1 & 3.2 \\
\hline \multirow[t]{4}{*}{1} & 1.4 & 1 & 1.45 & & & 2 & 3.9 & 1 & 2.7 \\
\hline & & & & & & 1 & 3.5 & 1 & 0.5 \\
\hline & & & & & & 1 & 3.1 & & \\
\hline & & & & & & 1 & 1.8 & & \\
\hline 13 & 135.3 & 13 & 135.55 & 11 & 133.7 & 18 & 134.6 & 14 & 134.65 \\
\hline \multicolumn{2}{|c|}{ Foxtail millet } & \multicolumn{2}{|c|}{ Sorghum } & \multicolumn{2}{|c|}{ Maize } & \multicolumn{2}{|c|}{ Job's tears } & \multicolumn{2}{|c|}{ Rice } \\
\hline $\begin{array}{l}\text { Copy } \\
\text { no. }\end{array}$ & $\begin{array}{l}\text { Mol. } \\
\text { size }\end{array}$ & $\begin{array}{l}\text { Copy } \\
\text { no. }\end{array}$ & $\begin{array}{l}\text { Mol. } \\
\text { size }\end{array}$ & $\begin{array}{c}\text { Copy } \\
\text { no. }\end{array}$ & $\begin{array}{l}\text { Mol. } \\
\text { size }\end{array}$ & $\begin{array}{c}\text { Copy } \\
\text { no. }\end{array}$ & $\begin{array}{l}\text { Mol. } \\
\text { size }\end{array}$ & $\begin{array}{c}\text { Copy } \\
\text { no. }\end{array}$ & $\begin{array}{l}\text { Mol. } \\
\text { size }\end{array}$ \\
\hline 1 & 18.5 & 1 & 33.0 & 1 & 18.3 & 1 & 17.3 & 1 & 19.0 \\
\hline 1 & 16.2 & 1 & 17.2 & 1 & 16.6 & 1 & 16.0 & 1 & 16.5 \\
\hline 1 & 14.6 & 1 & 16.2 & 1 & 15.5 & 1 & 14.5 & 1 & 15.0 \\
\hline 1 & 13.8 & 1 & 14.6 & 1 & 14.5 & 1 & 13.8 & 1 & 13.6 \\
\hline 1 & 12.6 & 1 & 12.6 & 1 & 12.6 & 1 & 12.6 & 1 & 11.1 \\
\hline 1 & 11.0 & 1 & 8.4 & 1 & 11.0 & 1 & 11.0 & 1 & 10.0 \\
\hline 1 & 10.5 & 3 & 5.4 & 1 & 8.4 & 1 & 8.5 & 2 & 8.8 \\
\hline 3 & 5.4 & 1 & 4.6 & 3 & 5.4 & 3 & 5.4 & 1 & 8.3 \\
\hline 1 & 5.0 & 1 & 3.85 & 1 & 5.0 & 1 & 5.0 & 1 & 5.4 \\
\hline 1 & 4.7 & 1 & 3.6 & 1 & 4.6 & 1 & 4.65 & 1 & 4.9 \\
\hline 1 & 3.9 & 2 & 3.15 & 1 & 3.8 & 1 & 4.55 & 1 & 4.7 \\
\hline 2 & 3.15 & 1 & 1.9 & 2 & 3.45 & 1 & 3.9 & 1 & 4.0 \\
\hline 1 & 1.9 & 1 & 0.7 & 1 & 3.1 & 1 & 3.7 & 1 & 2.2 \\
\hline 1 & 1.55 & 1 & 0.5 & 2 & 1.85 & 2 & 3.15 & 1 & 1.8 \\
\hline 1 & 1.4 & & & 1 & 0.7 & 1 & 1.9 & & \\
\hline 1 & 0.7 & & & 1 & 0.5 & 1 & 0.7 & & \\
\hline 1 & 0.5 & & & & & & & & \\
\hline 20 & 139.35 & 17 & 139.65 & 20 & 141.4 & 19 & 140.6 & 15 & 134.1 \\
\hline
\end{tabular}


Table 4. Molecular size (kbp) and copy number of individual SalIrestriction fragments of ctDNAs of ten cereals

\begin{tabular}{|c|c|c|c|c|c|c|c|c|c|}
\hline \multicolumn{2}{|c|}{ Wheat } & \multicolumn{2}{|c|}{ Rye } & \multicolumn{2}{|c|}{ Barley } & \multicolumn{2}{|c|}{ Oats } & \multicolumn{2}{|c|}{ Finger millet } \\
\hline $\begin{array}{l}\text { Copy } \\
\text { no. }\end{array}$ & $\begin{array}{l}\text { Mol. } \\
\text { size }\end{array}$ & $\begin{array}{c}\text { Copy } \\
\text { no. }\end{array}$ & $\begin{array}{l}\text { Mol. } \\
\text { size }\end{array}$ & $\begin{array}{c}\text { Copy } \\
\text { no. }\end{array}$ & $\begin{array}{l}\text { Mol. } \\
\text { size }\end{array}$ & $\begin{array}{c}\text { Copy } \\
\text { no. }\end{array}$ & $\begin{array}{l}\text { Mol. } \\
\text { size }\end{array}$ & $\begin{array}{c}\text { Copy } \\
\text { no. }\end{array}$ & $\begin{array}{l}\text { Mol. } \\
\text { size }\end{array}$ \\
\hline 1 & 27.2 & 1 & 27.2 & 1 & 27.2 & 1 & 27.2 & 2 & 21.8 \\
\hline 1 & 21.8 & 1 & 21.8 & 1 & 21.8 & 1 & 13.6 & 1 & 14.5 \\
\hline 1 & 14.2 & 1 & 14.2 & 1 & 14.2 & 1 & 11.8 & 1 & 13.6 \\
\hline 1 & 13.6 & 1 & 13.6 & 1 & 14.0 & 2 & 9.2 & 1 & 13.2 \\
\hline 1 & 11.8 & 1 & 11.8 & 1 & 13.6 & 1 & 8.6 & 1 & 11.8 \\
\hline 3 & 7.2 & 3 & 7.2 & 1 & 11.8 & 1 & 8.0 & 1 & 7.3 \\
\hline 1 & 6.8 & 1 & 6.8 & 2 & 7.2 & 3 & 7.2 & 3 & 7.0 \\
\hline 1 & 6.2 & 1 & 6.3 & 1 & 6.2 & 1 & 7.0 & 1 & 4.1 \\
\hline 2 & 4.5 & 2 & 4.5 & 2 & 4.5 & 1 & 4.95 & 1 & 3.25 \\
\hline 1 & 1.2 & 1 & 1.2 & 1 & 1.2 & 2 & 4.5 & 1 & 1.1 \\
\hline 1 & 1.1 & 1 & 1.1 & 1 & 1.1 & 1 & 4.1 & 1 & 0.8 \\
\hline 1 & 0.8 & 1 & 0.8 & 1 & 0.8 & & & 1 & 0.7 \\
\hline 15 & 135.3 & 15 & 135.4 & 14 & 135.3 & 15 & 134.25 & 15 & 134.95 \\
\hline \multicolumn{2}{|c|}{ Foxtail millet } & \multicolumn{2}{|c|}{ Sorghum } & \multicolumn{2}{|c|}{ Maize } & \multicolumn{2}{|c|}{ Job's tears } & \multicolumn{2}{|c|}{ Rice } \\
\hline $\begin{array}{l}\text { Copy } \\
\text { no. }\end{array}$ & $\begin{array}{l}\text { Mol. } \\
\text { size }\end{array}$ & $\begin{array}{c}\text { Copy } \\
\text { no. }\end{array}$ & $\begin{array}{l}\text { Mol. } \\
\text { size }\end{array}$ & $\begin{array}{c}\text { Copy } \\
\text { no. }\end{array}$ & $\begin{array}{l}\text { Mol. } \\
\text { size }\end{array}$ & $\begin{array}{c}\text { Copy } \\
\text { no. }\end{array}$ & $\begin{array}{l}\text { Mol. } \\
\text { size }\end{array}$ & $\begin{array}{c}\text { Copy } \\
\text { no. }\end{array}$ & $\begin{array}{l}\text { Mol. } \\
\text { size }\end{array}$ \\
\hline 1 & 28.0 & 1 & 28.0 & 1 & 28.0 & 1 & 28.0 & 1 & 28.0 \\
\hline 2 & 22.5 & 1 & 23.1 & 1 & 23.1 & 1 & 23.1 & 1 & 21.4 \\
\hline 1 & 12.8 & 2 & 15.5 & 2 & 15.5 & 1 & 15.5 & 1 & 15.8 \\
\hline 1 & 11.8 & 1 & 11.8 & 1 & 11.8 & 1 & 13.2 & 1 & 14.8 \\
\hline 1 & 8.9 & 1 & 8.9 & 1 & 8.9 & 1 & 11.8 & 2 & 13.2 \\
\hline 3 & 7.3 & 3 & 7.3 & 3 & 7.3 & 1 & 8.9 & 1 & 7.6 \\
\hline 1 & 7.0 & 1 & 7.0 & 1 & 7.0 & 3 & 7.3 & 2 & 7.4 \\
\hline 1 & 1.95 & 1 & 6.8 & 1 & 6.7 & 1 & 6.85 & 1 & 6.9 \\
\hline 1 & 1.1 & 1 & 1.1 & 1 & 1.1 & 1 & 6.7 & & \\
\hline 1 & 0.8 & 1 & 0.7 & 1 & 0.9 & 1 & 1.95 & & \\
\hline \multirow[t]{3}{*}{1} & 0.7 & & & 1 & 0.7 & 1 & 1.1 & & \\
\hline & & & & & & 1 & 0.9 & & \\
\hline & & & & & & 1 & 0.7 & & \\
\hline 14 & 139.95 & 13 & 140.3 & 14 & 141.1 & 15 & 140.6 & 10 & 135.7 \\
\hline
\end{tabular}

rye-barley relationship which supports the fact that wheat and rye are placed in the same subtribe, Triticinae, whereas barley is placed in another subtribe, Hordeinae of Triticeae.

Chloroplast genomes of maize and job's tears which belong to the same 


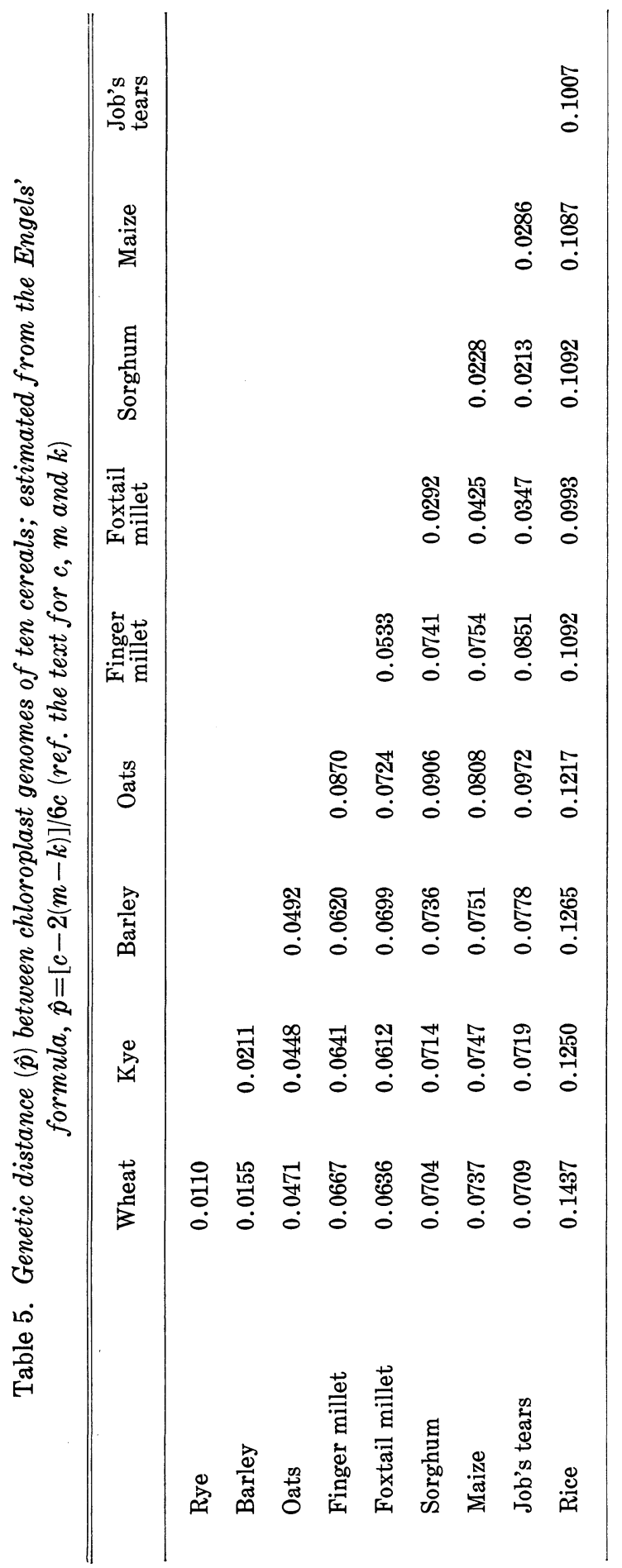




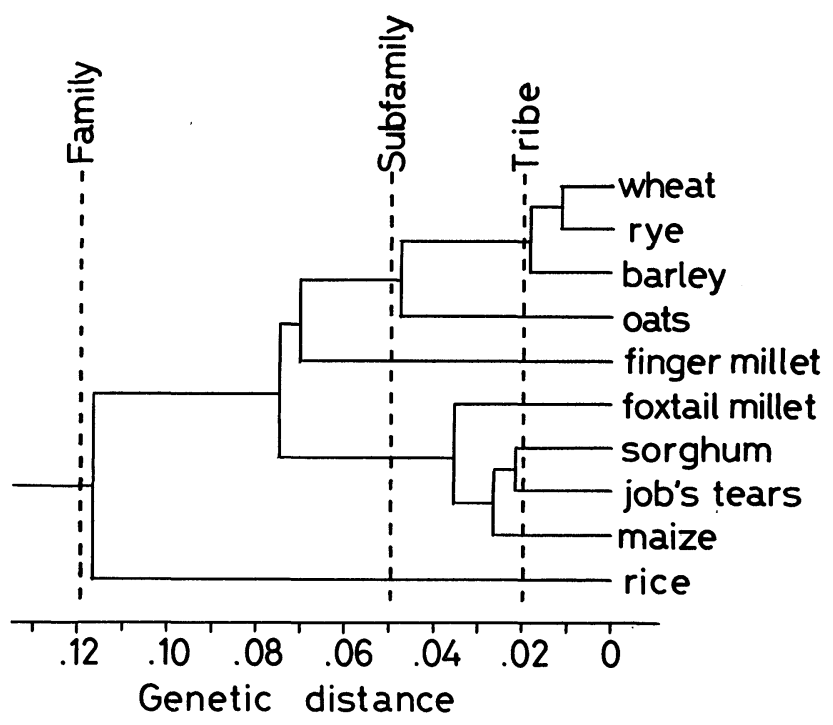

Fig. 5. A phylogenetic tree of the chloroplast genomes for ten cereals; drawn by the UPGMA method (Sneath and Sokal 1973) applied to the matrix of genetic distances shown in Table 5. The critical levels of classifying taxa to separate tribes, subfamilies and families are indicated by the broken lines.

tribe, Maydeae, showed a close relationship with $\hat{p}=0.029$. However, the chloroplast genome of sorghum that belong to another tribe, Andropogoneae, of the same subfamily, was more closely related to those of maize and job's tears ( $\hat{p}=0.023$ and 0.021 , respectively), compared to the relationship between the chloroplast genomes of the latter two species. Furthermore, the genetic distance observed between chloroplast genomes of maize and job's tears was the same as that between chloroplast genomes of sorghum (tribe Andropogoneae) and foxtail millet (tribe Paniceae). Therefore, the validity of placing the two genera, Zea and Coix, into the same tribe becomes questionable. The present ctDNA data are in support of separating these genera into different tribes. The fact that Zea and its related genera are of New World origin, whereas Coix and its related genera are all of Old World origin supports the present proposition. If this proposition is accepted, the genetic distance, $\hat{p}=$ 0.02 , can be used as the critical value for separating two taxa into different tribes.

The chloroplast genome of oats belonging to the tribe Agrosteae showed moderately close relationships $(\hat{p}=0.045-0.049)$ to those of wheat, rye and barley, all belonging to another tribe Triticeae. This fact is in agreement with the fact that both tribes are included in the same subfamily, Pooideae. The present phylogenetic relationships among the four cereals of this subfamily are in agreement with those previously reported by Vedel et al. (1980), 


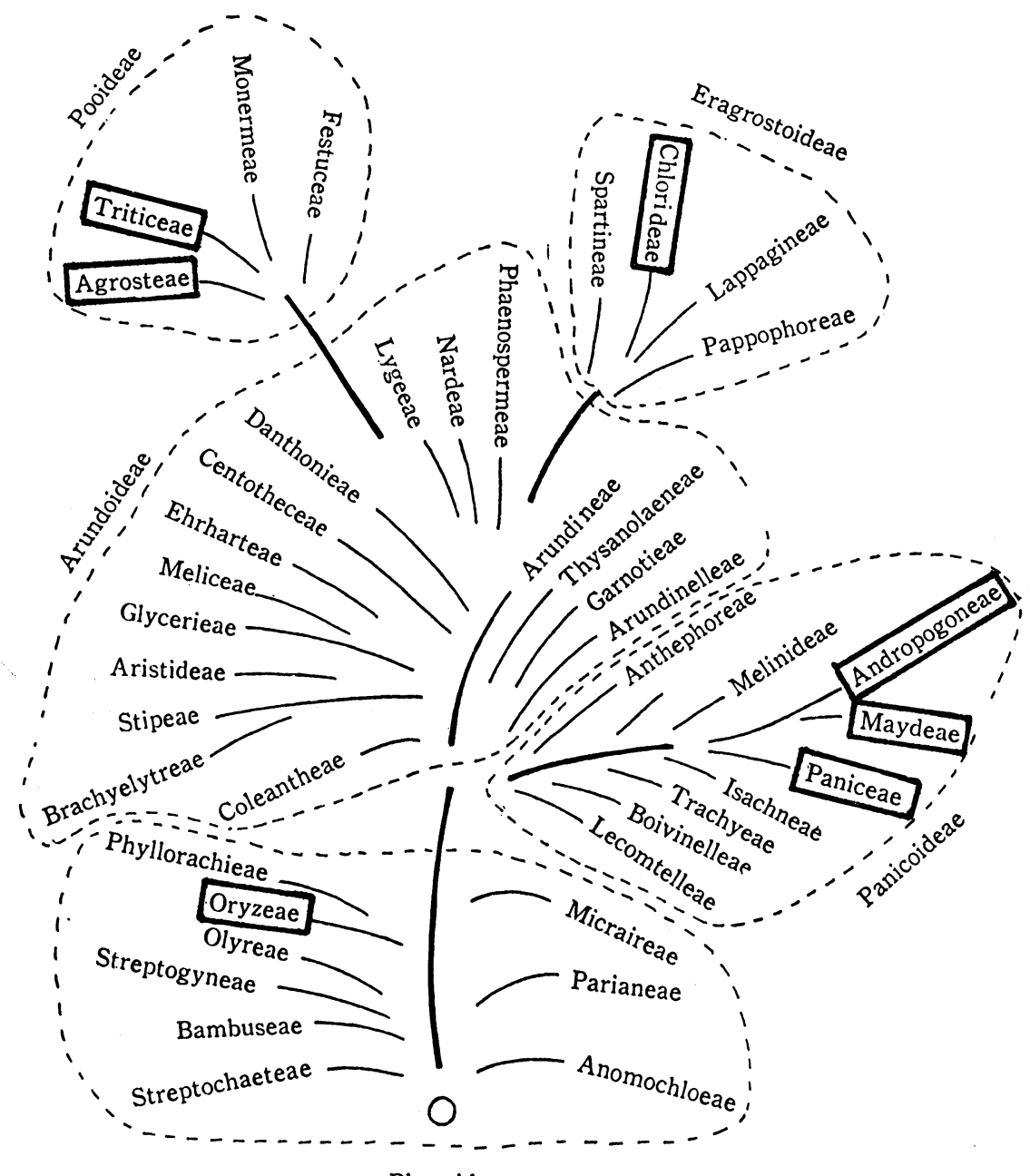

Pharoideae

Fig. 6. A phylogenetic tree of the family, Gramineae, that is based on conventional systematic data (cited from Tateoka 1957).

based on the results of cytoplasmic DNA variation. The chloroplast genome of foxtail millet belonging to the tribe Paniceae, sorghum in the tribe Andropogoneae, and job's tears and maize in Maydeae, all three tribes of which belong to the same subfamily, Panicoideae, had a $\hat{p}$ value of 0.021 to 0.043 . The genetic distance observed between two species belonging to different tribes of the same subfamily was within the range of $\hat{p}=0.021-0.049$. On the other hand, the genetic distance observed between two species belonging to different subfamilies was within the range of $\hat{p}=0.053-0.144$. Thus, the genetic distance, $\hat{p}=0.05$, is regarded as a critical value for classifying two 
species into different subfamilies.

The present results also revealed that among the four subfamilies, Eragrostoideae and Pooideae were the most closely related with each other, Panicoideae being next closest. Pharoideae was the most distant to all other subfamilies. These relationships are in complete agreement with their phylogenetic relationships determined by conventional systematic studies (cf. Figs. 5 and 6). In conclusion, the phylogenetic relationships among chloroplast genomes of the ten cereals revealed by the present restriction endonuclease analysis of their ctDNAs are in good agreement with those derived from the traditional systematic studies. This fact provides a sound basis for our future investigations on the phylogenetic origin of important crop species by the restriction endonuclease analysis of the organellar DNAs of the crop species and their wild relatives.

We would like to express our heartful thanks to Dr. S. Nonaka, the Kyushu Agricultural Experiment Station, Chikugo, Mr. T. Fukuoka, the Chugoku Agricultural Experiment Station, Fukuyama, and Drs. H. Maeda and H. Sato, the Agricultural Research Center, Ministry of Agriculture, Forestry and Fishery, Tsukuba, for their kind gift of the seeds of wheat, job's tears and rice, respectively. We owe thanks to Dr. S. Tsuji of our laboratory for his help in the computer analysis of the present data, and to Dr. M. Murakami, the Kyoto Prefectural University for providing useful informations on the phylogenetic relationships among Coix, Zea and Sorghum.

\section{REFERENCES}

Atchinson, B. A., Whitfeld, P. R. and Bottomley, W. (1976) Comparison of chloroplast DNAs by specific fragmentation with EcoRI endonuclease. Mol. Gen. Genet. 148, 263-269.

BEDBROOK, J. R. and BOGORAD, L. (1976) Endonuclease recognition sites mapped on Zea mays chloroplast DNA. Proc. Natl. Acad. Sci. USA 73, 4309-4313.

Bedbrook, J. R., Coen, D. M., Beaton, A. R., Bogorad, L. and Rich, A. (1979) Location of the single gene for the large subunit of ribulose bisphosphate carboxylase on the maize chloroplast chromosome. 'J. Biol. Chem. 254, 905-910.

Berthou, F., Mathieu, C. and Vedel, F. (1983) Chloroplast and mitochondrial DNA variation as indicator of phylogenetic relationships in the genus Coffea L. Theor. Appl. Genet. 65, 77-84.

Bowman, C. M., Bonnard, G. and Dyer, T. A. (1983) Chloroplast DNA variation between species of Triticum and Aegilops. Location of the variation on the chloroplast genome and its relevance to the inheritance and classification of the cytoplasm. Theor. Appl. Genet. 65, 247262.

Bowman, C. M., Koller, B., Delius, H. and Dyer, T. A. (1981) A physical map of wheat chloroplast DNA showing the location of the structural genes for the ribosomal RNAs and the large subunit of ribulose 1, 5-bisphosphate carboxylase. Mol. Gen. Genet. 183, 93-101.

Clegg, M. T., Rawson, J. R. Y. and Thomas, K. (1984) Chloroplast DNA variation in pearl millet and related species. Genetics 106, 449-461.

ENGELS, W. R. (1981) Estimating genetic divergence and genetic variability with restriction endonucleases. Proc. Natl. Acad. Sci. USA 78, 6329-6333.

Gordon, K. H. J., Crouse, E. J., Bohnert, H. J. and Herrmann, R. G. (1982) Physical mapping of differences in chloroplast DNA of the five wild-type plastomes in Oenothera subsection Euoenothera. Theor. Appl. Genet. 61, 373-384.

Hirai, A., Ichikawa, H., Iwatsuki, N. and Sugiura, M. (1985) Rice chloroplast DNA: a phy- 
sical map and the location of the genes for the large subunit of ribulose 1, 5-bisphosphate carboxylase and the $32 \mathrm{KD}$ photosystem II reaction center protein. Theor. Appl. Genet. 70, 117-122.

Hosaka, K., Ogihara, Y., Matsubayashi, M. and Tsunewaki, K. (1984) Phylogenetic relationship between the tuberous Solanum species as revealed by restriction endonuclease analysis of chloroplast DNA. Jpn. J. Genet. 59, 349-369.

Kung, S. D., Zhu, Y. S. and Shen, G. F. (1982) Nicotiana chloroplast genome. III. Chloroplast DNA evolution. Theor. Appl. Genet. 61, 73-79.

Levings, C. S. III and PRING, D. R. (1976) Restriction endonuclease analysis of mitochondrial DNA from normal and Texas cytoplasmic male-sterile maize. Science 193, 158-160.

OGIHARA, Y. and TSUNEWAKI, K. (1982) Molecular basis of the genetic diversity of the cytoplasm in Triticum and Aegilops. I. Diversity of the chloroplast genome and its lineage revealed by the restriction pattern of ctDNAs. Jpn. J. Genet. 57, 371-396.

Ogihara, Y. and TsunewakI, K. (1984) The diversity of chloroplast DNA among Triticum and Aegilops species. Proc. VI Int. Wheat Genet. Symp. 407-413.

Palmer, J. D., Shields, C. R., Cohen, D. B. and Orton, T. J. (1983) Chloroplast DNA evolution and the origin of amphidiploid Brassica species. Theor. Appl. Genet. 65, 181-189.

Palmer, J. D., Singh, G. P. and Pillary, D. T. N. (1983) Structural and sequence evolution of three legume chloroplast DNAs. Mol. Gen. Genet. 190, 13-19.

PALmer, J. D. and ZAMIR, D. (1982) Chloroplast DNA evolution and phylogenetic relationships in Lycopersicon. Proc. Natl. Acad. Sci. USA 79, 5006-5010.

Sneath, P. H. A. and Sokal, R. R. (1973) Numerical Taxonomy. pp. 573. Freeman \& Co., San Francisco.

TATEOKA, T. (1957) Miscellaneous papers on the phylogeny of Poaceae. X. Proposition of a new phylogenetic system of Poaceae. J. Japan. Bot. 32, 275-287.

Tfrachi, T., Ogihara, Y. and Tsunewaki, K. (1984) The molecular basis of genetic diversity among cytoplasms of Triticum and Aegilops. III. Chloroplast genomes of the M and modified M genome-carrying species. Genetics 108, 681-695.

Timothy, D. H., Levings, C. S., Pring, D. R., Conde, M. F. and Kernicke, J. L. (1979) Organelle DNA variation and systematic relationships in the genus Zea: Teosinte. Proc. Natl. Acad. Sci. USA 76, 4220-4224.

Tsunewaki, K. and OGIHARA, Y. (1983) The molecular basis of genetic diversity among cytoplasms of Triticum and Aegilops species. II. On the origin of polyploid wheat cytoplasms as suggested by chloroplast DNA restriction fragment patterns. Genetics 104, 155-171.

Vedel, F., LebacQ, P. and Quetier, F. (1980) Cytoplasmic DNA variation and relationships in cereal genomes. Theor. Appl. Genet. 58, 219-224.

Vedel, F., Quetier, F. and BAyen, M. (1976) Specific cleavage of chloroplast DNA from higher plants by EcoRI restriction nuclease. Nature 263, 440-442.

Vedel, F., Quetier, F., Dosba, F. and Doussinault, G. (1978) Study of wheat phylogeny by EcoRI analysis of chloroplastic and mitochondrial DNAs. Plant Sci. Lett. 13, 97-102. 